\title{
KOMPOSISI BAHASA MELAYU PALEMBANG: SEBUAH KAJIAN MORFOLOGIS
}

\author{
Andina Muchti \\ Universitas Bina Darma \\ Jalan Jenderal Ahmad Yani No.3 Palembang, Sumatera Selatan, Indonesia \\ Email: andina.muchti@binadarma.ac.id
}

\begin{abstract}
Abstrak
Tujuan penelitian ini adalah untuk mendeskripsikan bentuk dan makna komposisi bahasa Melayu Palembang. Objek penelitian difokuskan pada proses morfologis dalam bahasa Melayu Palembang, yaitu pada bentuk dan makna komposisi. Metode penelitian yang digunakan yaitu metode distribusional. Data diperoleh dengan cara observasi dan dokumentasi, yaitu mendokumentasikan bahasa Melayu Palembang yang bersumber dari kamus bahasa Palembang. Komposisi berdasarkan hubungan unsur-unsur pendukungnya, yaitu gabungan kata dengan kata dan gabungan antara pokok kata dengan pokok kata. Dari hasil terdapat dua bentuk komposisi dalam bahasa Melayu Palembang, yakni (1) bentuk majemuk yang unsur pertamanya menjadi pusat atau diterangkan (D) oleh unsur penjelas/menerangkan (M) dan (2) bentuk majemuk yang unsur-unsurnya tidak saling menerangkan, tetapi hanya berupa rangkaian yang sejajar (kopulatif). Makna komposisi bahasa Melayu Palembang tidak bergantung dengan makna unsur yang membentuknya karena komposisi itu membentuk makna baru yang tidak sama dengan makna aslinya. Makna yang timbul dari proses komposisis dalam bahasa Melayu Palembang ada lima, yaitu ampas/kotoran, keluarga kandung, keadaan, sifat, dan komposisi bermakna alat. Berbeda dengan penelitian sebelumnya terdapat dua makna yang timbul dari proses komposisi bahasa Melayu Palembang, yaitu makna proses dan keadaan.
\end{abstract}

Kata kunci: komposisi, bentuk, makna, bahasa Melayu Palembang, morfologis

\section{COMPOSITION OF THE PALEMBANG MALAY LANGUAGE: A MORPHOLOGICAL STUDY}

\begin{abstract}
The purpose of this study was to describe the form and meaning of the Palembang Malay composition. The object of research is focused on the morphological process in Palembang Malay, namely on the form and meaning of the composition. The research method used is the distributional method. The data were obtained by means of observation and documentation, namely documenting the Palembang Malay which was sourced from the Palembang language dictionary. The composition is based on the relationship of the supporting elements, namely a combination of words for words and a combination of main words and main words. From the results, there are two forms of composition in Palembang Malay, namely (1) a compound form whose first element becomes the center/explained (D) by an explanatory element (M) and (2) a compound form whose elements do not explain each other, but only a series of parallel or
\end{abstract}


copulative. The meaning of the Palembang Malay composition does not depend on the meaning of the elements that make it up because the composition forms a new meaning that is not the same as the original meaning. There are five meanings arising from the compositional process in Palembang Malay, namely dregs/feces, biological family, condition, characteristics, and meaningful composition of tools. In contrast to previous studies, there are two meanings arising from the composition process of the Palembang Malay language, namely the meaning of process and state.

Keywords: composition, form, meaning, Palembang Malay, morphology

\section{A. Pendahuluan}

Mempertahankan sebuah bahasa daerah dari kepunahan salah satunya dengan cara mengaji bahasa itu lebih mendalam lagi. Terdapat banyak teori proses morfologi yang dapat digunakan untuk mengajinya. Salah satu proses itu yakni proses komposisi bahasa.

Chaer (2008:209) mengemukakan komposisi bahasa merupakan proses penggabungan dasar dengan dasar yang biasanya berupa akar maupun bentuk berimbuhan untuk mewadahi sebuah konsep yang belum tertampung dalam sebuah kata. Seperti diketahui bahwasanya banyak sekali konsep dalam kehidupan sehari-hari, khususnya dalam bahasa daerah, sementara jumlah kosakata dalam bahasa itu terbatas.

Perkembangan bahasa Indonesia mengalami proses yang cukup lama agar dapat dipahami dan diterima oleh masyarakat di Indonesia. Perkembangan bahasa yang dialami oleh Indonesia ini salah satunya didukung oleh adanya bahasa daerah (Noermanzah, 2017). Salah satu rumpun bahasa daerah yang mendukung perkembangan bahasa Indonesia yaitu rumpun bahasa Melayu.

Salah satu rumpun bahasa Melayu yang digunakan adalah bahasa Melayu Palembang. Menurut Suhardi (dalam Masinambow \& Haenen, 2002) antara bahasa Indonesia dengan bahasa daerah memiliki keterkaitan yang cukup erat. Keterkaitan tersebut salah satunya yaitu kosakata bahasa Indonesia yang sangat beragam itu diperkaya dengan mengambil unsur-unsur bahasa daerah begitupun sebaliknya. Dengan demikian, ada kaitan antara bahasa Indonesia dengan bahasa Melayu Palembang yakni bahasa Melayu Palembang menjadi salah satu bahasa penyumbang kosakata dalam bahasa Indonesia. Bahasa Indonesia 
berasal dari bahasa Melayu yang bersifat terbuka terhadap bahasa lain. Sementara bahasa Palembang termasuk ke dalam kategori bahasa Melayu.

Ada banyak rumpun bahasa Melayu yang terdapat di Indonesia. Di antara bahasa Melayu satu dengan yang lainnya memiliki perbedaan. Perbedaan itu karena adanya perbedaan letak geografis pemakaian bahasa yang beragam, sehingga dapat mempengaruhi bentuk kosakata yang ada dalam bahasa Melayu tersebut. Sementara itu, ada dua proses pembentukan kata, yaitu proses morfologis dan nonmorfologis. Proses morfologis merupakan pembentukan kata dengan cara menghubungkan morfem satu dengan morfem lainnya atau proses penggabungan morfem menjadi kata. Proses nonmorfologis merupakan pembentukan kata yang tidak melalui proses yang terdapat di dalam morfologi.

Kridalaksana (2008:930), menerangkan morfologi adalah cabang ilmu linguistik tentang morfem dan kombinasinya serta ilmu bentuk kata. Sementara itu, menurut Ramlan (2009:21) dan Ermanto (2016), morfologi adalah bagaian dari ilmu bahasa yang membicarakan atau mempelajari seluk-beluk bentuk kata serta pengaruh perubahan-perubahan bentuk kata terhadap golongan dan arti kata. Kridalaksana (2008:159) menyebutkan bahwa morfologi, yaitu (a) bidang linguistik yang mempelajari morfem dan kombinasi-kombinasinya; (b) bagian dari struktur bahasa yang mencakup kata dan bagian-bagian kata, yaitu morfem. Sementara itu, menurut Suhardi (2008: 23) morfologi sebagai salah satu cabang ilmu bahasa mengaji masalah-masalah yang terkait dengan struktur kata.

Pembentukan sebuah kata dalam suatu bahasa tidak terlepas dari adanya proses morfologis. Proses morfologis adalah suatu cara dalam membentuk kata dengan menambahkan morfem yang satu dengan morfem yang lain. Menurut Soeparno (2002:95), proses morfologis adalah peristiwa pembentukan kata kompleks atau kata polimorfemis secara diakronis. Sementara itu, menurut Ramlan (2009:51) proses morfologis adalah proses pembentukan kata-kata dari satuan lain yang merupakan bentuk dasarnya.

Kridalaksana (2008:202) menyatakan proses morfologis sebagai proses yang mengubah leksem menjadi kata. Dalam proses morfologis proses yang 
utama atau yang awal adalah derivasi zero, afiksasi, reduplikasi, komposisi, dan abreviasi (pemendekan), serta derivasi balik.

Dalam Kamus Linguistik yang ditulis oleh Kridalaksana (2008:202) disebutkan bahwa proses morfologis adalah proses yang mengubah leksem menjadi kata, dalam hal ini leksem merupakan input dan kata merupakan output, proses morfologis yang utama ialah derivasi zero, afiksasi, reduplikasi, abreviasi, komposisi, derivasi balik.

Macam-macam proses morfologis adalah sebagai berikut: 1) pembentukan kata dengan menambahkan morfem afiks pada bentuk dasar; 2) pembentukan kata dengan mengulang bentuk dasar; dan 3) pembentukan kata dengan menggabungkan dua atau lebih bentuk dasar. Pernyataan tersebut dapat dijelaskan bahwa proses morfologis merupakan sebuah proses yang menghubungkan antara morfem yang satu dengan yang lainnya dari bentuk dasarnya. Dalam hal ini, proses morfologis yang dijelaskan oleh Ramlan (2009:51) menitikberatkan pada pembentukan kata dari bentuk dasarnya. Selanjutnya, Muslich (2010:35) menyatakan proses morfologis terjadi karena adanya pembentukan dan penggabungan morfem yang satu dengan morfem yang lainnya sehingga menjadi kata. Dengan demikian, proses morfologis merupakan proses pembentukan kata yang disebabkan adanya pembentukan dan penggabungan antara morfem yang satu dengan morfem yang lain sehingga menjadi kata.

Kridalaksana (2007:104) menyatakan bahwa komposisi adalah proses penggabungan dua leksem atau lebih yang membentuk kata. Menurut Muslich (2010:57) menyebutkan komposisi adalah peristiwa bergabungnya dua morfem dasar atau lebih secara padu dan menimbulkan arti yang relatif baru. Sementara itu, Chaer (2008:209) menyatakan komposisi adalah proses penggabungan dasar dengan dasar (biasanya berupa akar maupun bentuk berimbuhan) untuk mewadahi suatu 'konsep' yang belum tertampung dalam sebuah kata.

Ramlan (2009:76) dan Fauziyah (2020) menyatakan bahwa kata majemuk adalah kata yang terdiri dari dua kata sebagai unsurnya. Sementara itu, menurut Verhaar (1996:154) kata majemuk adalah kata yang terdiri dari dua kata sebagai uns unsurnya atau salah satunya merupakan pokok kata dan yang lain adalah 
kata. Chaer (2008:210) dan Wahidah (2019) menyebutkan kata majemuk adalah penggabungan dua buah kata atau lebih yang memiliki makna baru. Dalam Kamus Linguistik yang ditulis oleh Kridalaksana (2008:111) dijelaskan bahwa kata majemuk adalah gabungan leksem dengan leksem seluruhnya berstatus sebagai kata yang mempunyai pola fonologis, gramatikal dan semantik yang khusus menurut kaidah bahasa yang bersangkutan, pola khusus tersebut membedakannya dari gabungan leksem yang bukan kata majemuk.

Muslich (2010:62) membagi tiga jenis bentuk majemuk berdasarkan hubungan unsur-unsur pendukungnya, yaitu (1) bentuk majemuk unsur pertama diterangkan (D) oleh unsur kedua (M), (2) bentuk majemuk yang unsur pertama menerangkan (M) unsur kedua (D), (3) bentuk majemuk yang unsur-unsurnya tidak saling menerangkan, tetapi hanya merupakan rangkaian yang sejajar (kopulatif). Sementara itu, Ramlan (2009:77) menyebutkan ciri-ciri kata majemuk sebagai berikut: 1) salah satu atau semua unsurnya berupa pokok kata, yang dimaksud dengan pokok kata adalah satuan gramatikal yang tidak dapat berdiri sendiri dalam tuturan biasa dan secara gramatikal tidak memiliki sifat bebas, yang dapat dijadikan bentuk dasar bagi suatu kata. Contohnya: juang, temu, alir, lomba, tempur, tahan renang, jual beli, dan jam kerja. Kemudian, 2) unsur-unsurnya tidak mungkin dipisahkan, atau tidak mungkin diubah strukturnya. Contohnya: kamar mandi, kaki tangan.

Peneliti menyimpulkan bahwa komposisi atau pemajemukan merupakan proses morfogogis yang menggabungkan dua morfem dasar menjadi kata. Hal itu bisa dijadikan pedoman dalam menganalisis proses morfologis berupa komposisi yang ada di dalam bahasa Melayu Palembang.

Penelitian tentang komposisi bahasa ini pernah dilakukan oleh Putri (2014) dengan judul Komposisi dan Makna Idiomatikal Kata Majemuk Nomina dalam Koran Kougaku Edisi 1 Juni 2011. Penelitian itu menunjukkan bahwa kata majemuk nomina bahasa Jepang dapat terbentuk dari komposisi berupa nomina +nomina, verba + nomina, adjektiva + nomina, nomina + verba yang dinominalkan, dan verba+verba yang dinominalkan. Jenis makna idiomatik kata majemuk 
nomina bahasa Jepang terdiri dari makna idiom, makna semi-idiom, dan makna non-idiom.

Penelitian ini dan penelitian milik Putri (2014) sama-sama membahas salah satu proses morfologis. Proses morfologis yang dibahas dalam kedua penelitian ini yaitu, komposisi. Kedua penelitian ini sama-sama membahas makna yang terdapat dalam data komposisi.

Hal yang membedakan penelitian di atas dengan penelitian ini, yaitu dalam penelitian sebelumnya Putri (2014) membahas komposisi dan makna idiomatik hanya pada kata nomina yang terdapat di Koran Kougaku. Sementara pada penelitian ini membahas proses morfologis komposisi dilihat dari bentuk dan maknanya. Selain itu, penelitian ini tuja tidak hanya membahas kelas kata nomina saja, tetapi juga pada kelas kata yang lainnya. Penelitian ini juga membahas komposisi pada bahasa daerah, yakni bahasa Melayu Palembang.

Bahasa Melayu Palembang memiliki cukup banyak istilah dengan menggabungkan dua kata atau lebih. Penggabungan itu dapat membentuk makna baru yang relatif berbeda dari morfem dasarnya. Proses penggabungan itu merupakan salah satu bentuk proses morfologis, yakni komposisi. Proses komposisi inilah yang dijadikan objek dalam penelitian ini.

Penelitian terkait proses morfologis bahasa Melayu Palembang pernah diteliti oleh Yasiroh (2013). Dalam penelitiannya Yasiroh mengaji bentuk, makna, dan fungsi afiksasi, reduplikasi, dan komposisi. Data diperoleh dengan studi pustaka berupa cerita-cerita rakyat dan pantun bahasa Melayu Palembang. Penelitian itu menghasilkan dua makna komposisi yaitu menyatakan makna proses dan keadaan. Sedangkan dalam penelitian ini mengaji bentuk dan makna komposisi dengan data yang lebih banyak lagi. Data-data itu bersumber dari hasil obeservasi peneliti terhadap penutur bahasa Melayu Palembang dan dari kamus bahasa Palembang.

Berdasarkan latar belakang di atas, tujuan dalam penelitian ini yaitu, untuk mendeskripsikan komposisi dilihat dari bentuk dan maknanya yang terjadi dalam bahasa Melayu Palembang. Hasil penelitian ini diharapkan dapat memberikan pengetahuan dan ilmu atau teori-teori linguistik dalam menganalisis kebahasaan 
khususnya tentang komposisi dalam bahasa Melayu Palembang, yakni dengan tujuan untuk kemajuan dan perkembangan ilmu bahasa atau linguistik.

\section{B. Metode Penelitian}

Metode yang digunakan dalam penelitian ini, yaitu metode distribusional. Sudaryanto (1993:15) menyebutkan metode distribusional merupakan metode menganalisis data sesuai dengan data, yakni menggunakan alat penentu dari unsur bahasa itu sendiri. Sesuai dengan pernyataan Sudaryanto (1993:15) tersebut maka penelitian ini dalam melakukan pemilihan data berdasarkan kriteria tertentu dari segi kegramatikalan sesuai dengan bahasa yang diteliti. Dalam penelitian ini, kriteria yang digunakan adalah proses pembentukan kosakata secara morfologis.

Penelitian ini menggunakan pendekatan deskriptif kualittaif. Peneliti mendeskripsikan bentuk dan makna komposisi dalam bahasa Melayu Palembang. dengan cermat dan mempertimbangkan masalah-masalah yang ada di dalam data. Penelitian ini menggunakan studi pustaka yakni kamus bahasa Melayu Palembang yang diperkuat oleh studi lapangan berupa observasi untuk memperoleh data secara lisan.

Data dalam penelitian dikumpulkan dengan teknik observasi dan dokumentasi. Teknik observasi dilakukan dengan mengamati kosakata yang digunakan oleh penutur bahasa Melayu Palembang yang selanjutnya dilakukan teknik dokumentasi dengan mengumpulkan data berupa kosakata kompleks atau gabungan kata yang terdapat di dalam kamus bahasa Melayu Palembang. Selain melakukan kedua teknik tersebut, peneliti juga memanfaatkan dirinya sendiri sebagai sumber data dan instrumen penelitian karena peneliti juga sebagai penutur asli bahasa Melayu Palembang.

Selanjutnya, peneliti membuat kategorisasi atau pengelompokan berdasarkan bentuk dan makna komposisi dalam bahasa Melayu Palembang. Selanjutnya, dilakukan pemilihan data yang akan dianalisis. Pemilihan data penelitian ini berdasarkan kriteria tertentu dari segi kegramatikalan sesuai dengan 
bahasa yang diteliti. Dalam penelitian ini, kriteria yang digunakan adalah proses pembentukan kosakata secara morfologis.

\section{Hasil Penelitian dan Pembahasan}

\section{Hasil Penelitian}

Penelitian ini menghasilkan data berupa bentuk dan makna komposisi bahasa Melayu Palembang. Bentuk komposisi dalam bahasa Melayu Palembang terdiri dari dua macam, yakni: (1) bentuk majemuk yang unsur pertamanya menjadi pusat/diterangkan (D) oleh unsur kedua penjelas/menerangkan (M) dan (2) bentuk majemuk yang unsur-unsurnya tidak saling menerangkan, tetapi hanya rangkaian yang sejajar (kopulatif). Makna komposisi bahasa Melayu Palembang tidak bergantung dengan makna unsur yang membentuknya. Hal itu karena komposisi itu membentuk makna baru yang tidak sama dengan makna aslinya. Untuk lebih jelasnya dapat ditunjukkan bentuk dan makna komposisi bahasa Melayu Palembang pada tabel berikut.

Tabel 1. Bentuk dan Makna Komposisi dalam Bahasa Melayu Palembang

\begin{tabular}{|c|c|}
\hline Bentuk & Makna \\
\hline $\begin{array}{l}\text { 1. Unsur pusat/ diterangkan, unsur } \\
\text { penjelas/menerangkan (M-D). }\end{array}$ & $\begin{array}{l}\text { 1. Menyatakan makna } \\
\text { ampas/kotoran. }\end{array}$ \\
\hline $\begin{array}{l}\text { 2. Unsur-unsurnya tidak saling } \\
\text { menerangkan, tetapi merupakan } \\
\text { rangkaian yang sejajar. }\end{array}$ & $\begin{array}{l}\text { 2. Menyatakan makna keluarga } \\
\text { kandung. } \\
\text { 3. Menyatakan makna keadaan. } \\
\text { 4. Menyatakan makna sifat. } \\
\text { 5. Menyatakan makna alat. }\end{array}$ \\
\hline
\end{tabular}

\section{Pembahasan}

Hasil penelitian menunjukkan bahwa bentuk komposisi dalam bahasa Melayu Palembang terdiri dari dua macam, yakni: (1) bentuk majemuk yang unsur pertamanya menjadi pusat/diterangkan (D) oleh unsur kedua penjelas/menerangkan (M) dan (2) bentuk majemuk yang unsur-unsurnya tidak saling menerangkan, tetapi hanya rangkaian yang sejajar (kopulatif). Kemudian, makna komposisi bahasa Melayu Palembang tidak bergantung dengan makna unsur yang membentuknya. Hal itu karena komposisi itu membentuk makna baru yang tidak sama dengan makna aslinya. Berbeda dengan penelitian sebelumnya 
yang dilakukan oleh Yasiroh (2013) bahwa bentuk komposisi berdasarkan hubungan unsur-unsur pendukungnya, yaitu hanya sebatas gabungan kata dengan kata dan gabungan antara pokok kata dengan pokok kata. Tanpa memerhatikan kelas kata dan unsur-unsur pembentuknya.

Komposisi bahasa Melayu Palembang adalah gabungan kata (bentuk dasar) baik yang terbentuk dari kata benda (nomina), kata sifat (ajektiva), kata kerja (verba), maupun kata bilangan (numeralia). Di dalam bahasa Melayu Palembang, komposisi dapat disebut gabungan kata. Bentuk komposisi dalam bahasa Melayu Palembang yang ditemukan dari data pada penelitian ini terdiri dari dua macam, yakni sebagai berikut.

\section{a. Bentuk Komposisi Bahasa Melayu Palembang}

1) Bentuk Majemuk yang Unsur Pertama Pusat/Diterangkan (D) oleh Unsur Kedua Penjelas/Menerangkan (M).

Bentuk majemuk dalam bahasa Melayu Palembang dapat dibagi menjadi dua macam yaitu, (a) unsur kedua (sebagai M) berkelas ajektiva, (b) unsur kedua (sebagai M) berkelas kata selain kata ajektiva, yakni verba, nomina, dan numeralia.

(a) Unsur Kedua (sebagai M) Berkelas Ajektiva

- buto ijo

'buta hijau' (KB-KS)

- daon mudo

'daun muda' (KB-KS)

- jalo kerap 'jala rapat' (KB-KS)

- pagi buto 'pagi buta (KB-KS)

Bentuk komposisi di atas terdiri dari dua kata, yaitu kata 'buto' dan kata 'ijo'. Kata 'daon' dan kata 'mudo', kata 'jalo' dan kata 'kerap'. Kata tersebut unsur pertama adalah diterangkan (D) dan unsur kedua adalah menerangkan (M) berkelas kata sifat.

(b) Unsur kedua (sebagai m) memiliki kelas kata selain kata ajiktiva, yaitu verba, kata nomina dan numeralia. 


\section{(1) Unsur Kedua Kata Kerja}

- pecah utak 'pecah kepala' (KK-KB)

- ghuma makan 'rumah makan' (KB-KK)

- Anak ambe'an 'anak ambil/adopsi' (KB-KK)

Bentuk komposisi di atas terdiri dari dua kata, yaitu kata 'pecah' dan 'utak'. Kata 'ghuma' dan 'makan', kata 'anak' dan 'ambean'. Pada kata-kata di atas unsur pertamanya diterangkan (D) dan unsur kedua adalah menerangkan (M) berkelas kata kerja.

(2) Unsur Kedua Nomina

- tenga dalu 'tengah malam' (KB-KB)

- antu banyu 'hantu air' (KB-KB)

- dagha dageng 'darah daging (KB-KB)

Bentuk komposisi di atas terdiri dari dua kata, yaitu kata 'tenga' dan 'dalu'. Kata 'antu' dan 'banyu', kata 'dagha' dan 'dageng'. Kata-kata itu memiliki unsur pertama diterangkan (D) dan unsur kedua adalah menerangkan (M) berkelas kata benda.

(3) Unsur Kedua Numeralia

- Kaki limo

'Kaki lima' (KB-Kbil)

- Rai duobelas 'muka duabelas' (KB-Kbil)

- Ojong lapan 'ujung delapan' (KB-Kbil)

- Balak duobelas 'masalah duabelas' (KB-Kbil)

Bentuk komposisi di atas terdiri dari dua kata, yaitu kata 'kaki' dan 'limo', kata 'ojong' dan 'lapan', kata 'balak' dan 'duobelas'. Kata-kata itu unsur pertamanya adalah diterangkan (D) dan unsur kedua adalah menerangkan (M) berkelas kata bilangan. 
2) Bentuk majemuk yang unsur-unsurnya tidak saling menerangkan, tetapi hanya rangkaian yang sejajar (kopulatif).

Bentuk majemuk ini dalam bahasa Melayu Palembang dapat dilihat dari hubungan makna antarunsurnya. Hal ini terdapat tiga macam, yakni (a) hubungan setara, (b) hubungan berlawanan, dan (c) hubungan bersinonim.

(a) Bentuk Majemuk dengan Hubungan Setara

- Biji mato

Bola mata

- Tai lalet

'tahi lalat'

- Mato ati

'Mata hati'

Kata 'biji mato, 'tai lalet' dan 'mato ati' kata majemuk dengan hubungan setara, karena kata majemuk tersebut masih sama-sama dalam satu bagian atau satu tingkatan.

(b) Bentuk Majemuk dengan Hubungan Berlawanan

- naek toron 'naik turun

- Pocok bawah 'atas bawah'

- Tuo mudo 'tua muda'

- Buntu kayo 'miskin kaya'

Kata 'naek toron', 'pocok bawah', 'tuo mudo', dan 'buntu kayo' kata majemuk dengan hubungan berlawanan, karena kata majemuk tersebut memiliki makna yang berbeda, yakni berlawanan.

(c) Bentuk Majemuk dengan Hubungan Bersinonim

- tuo ghento

'tua renta'

- dak katek

'tidak tidak ada'

- lema lembot

'Lemah lembut'

Kata 'tuo ghento', 'dak katek' dan 'lema lembot' kata majemuk dengan hubungan bersinonim, karena kata majemuk tersebut memiliki makna yang sama. 


\section{b. Makna Komposisi Bahasa Melayu Palembang}

Makna komposisi bahasa Melayu Palembang tidak tergantung dari makna unsur pembentuknya. Hal itu karena makna yang terbentuk dari peristiwa komposisi itu merupakan makna baru yang tidak sama dengan makna asli dalam unsur-unsur pembentuknya.

Pada penelitian Yasiroh (2013), makna komposisi bahasa Melayu Palembang yang ditimbulkan hanya dua. Makna itu meliputi proses dan keadaan. Sedangkan dalam penelitian ini diperoleh lima makna komposisi bahasa melayu Palembang, yaitu makna ampas/kotoran, keluarga kandung, keadaan, sifat, dan alat. Makna komposisi bahasa Melayu Palembang yang diperoleh dari penelitian ini lebih lanjut dijabarkan sebagai berikut.

a). Menyatakan Makna Ampas/Kotoran

$$
\begin{aligned}
& \text { Bunga pasegh } \\
& \text { 'bunga pasir' } \\
& \text { Bunga pasir } \rightarrow \text { kotoran kucing }
\end{aligned}
$$

Kata bunga pasir ini memiliki makna yang tidak sama dengan makna asli dalam unsur-unsur pembentuknya, yaitu lepas dari makna unsur-unsurnya. kata bunga berarti 'bagian tumbuhan yang akan menjadi buah biasanya indah warnanya dan harum baunya, sementara kata pasir berarti 'butir-butir pasir yang halus'. Kata bunga pasir tidak lagi diartikan demikian, tetapi bunga pasir yang dimaksudkan adalah 'kotoran kucing'.

\section{b) Menyatakan Makna Keluarga Kandung}

$$
\begin{aligned}
& \text { Dagha dageng } \\
& \text { 'darah daging } \\
& \text { darah daging } \rightarrow \text { keluarga }
\end{aligned}
$$

Kata dagha daging ini memiliki makna yang tidak sama dengan makna aslinya dalam unsur-unsur pembentuknya, yaitu lepas dari arti unsur-unsurnya. Kata dagha berarti 'cairan terdiri dari sel merah dan sel putih yang berada di dalam tubuh', dan kata dageng berarti 'gumpalan lembut terdiri dari urat pada tubuh'. Kata darah daging tidak lagi diartikan demikian, tetapi dagha daging yang dimaksudkan adalah 'kandung atau keluarga'. 
c) Menyatakan Makna Keadaan

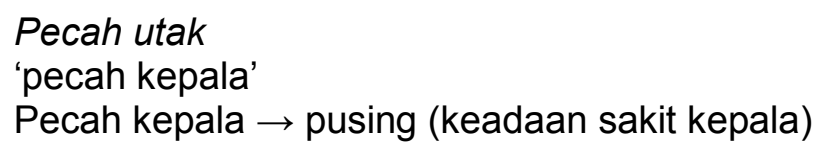

Kata pecah utak tidak memiliki makna yang sama dengan makna asli dalam unsur-unsur pembentuknya. Kata pecah berarti 'terbelah menjadi beberapa bagian', dan kata utak berarti 'bagian tubuh yang terdapat di dalam rongga tengkorak yang menjadi pusat syaraf'. Kata pecah utak bukan bermakna otak yang hancur menjadi beberapa bagian, tetapi bermakna 'pusing' (keadaan sakit kepala).

d) Menyatakan Makna Sifat

Geta basa

'getah basah'

Getah basah $\rightarrow$ pelit, kikir (sifat)

Kata geta basa tidak memiliki makna yang sama dengan makna asli dalam unsur-unsur pembentuknya. Kata geta bermakna 'zat cair dari batang pohon karet', sedangkan kata basa bermakna 'mengandung air atau barang cair'. Kata geta basa tidak bermakna demikian, tetapi memiliki arti pelit atau kikir (sifat tidak mau memberi/berbagi).

e) Menyatakan Makna Alat

$$
\begin{aligned}
& \text { Pokol besi } \\
& \text { 'pukul besi } \\
& \text { Pokol besi } \rightarrow \text { palu }
\end{aligned}
$$

Kata pokol besi tidak memiliki makna yang sama dengan makna asli dalam unsur-unsur pembentuknya. Kata pokol bermakna 'ketuk, sedangkan kata besi bermakna 'logam keras dan kuat'. Kata pokol besi bukan bermakna memukul logam keras dan kuat, tetapi memiliki arti palu (alat dari kayu untuk memukul paku). 


\section{Simpulan}

Berdasarkan hasil penelitan dan pembahasan yang telah dilakukan dapat disimpulkan bahwa terdapat dua bentuk komposisi dalam bahasa Melayu Palembang, yakni (1) bentuk majemuk yang unsur pertamanya menjadi pusat/diterangkan (D) oleh unsur penjelas/menerangkan (M) dan (2) bentuk majemuk yang unsur-unsurnya tidak saling menerangkan, tetapi hanya berupa rangkaian yang sejajar (kopulatif). Makna komposisi bahasa Melayu Palembang tidak bergantung dengan makna unsur yang membentuknya. Hal itu dikarenakan komposisi itu membentuk makna baru yang tidak sama dengan makna aslinya. Makna yang timbul dari proses komposisi dalam bahasa Melayu Palembang ada lima, yaitu komposisi bermakna ampas/kotoran, komposisi bermakna keluarga kandung, komposisi bermakna keadaan, komposisi bermakna sifat, dan komposisi bermakna alat.

Implikasi dari hasil penelitian ini dalam pembelajaran bahasa, bahwasanya pembelajaran bahasa Indonesia tidak akan terlepas dari kosakata. Kosakata itu digunakan baik dalam ragam lisan maupun tulis. Hal itu artinya peserta didik diharuskan memperkaya kosakata yang dikuasainya termasuk kosakata bahasa daerah. Selain itu, komposisi merupakan salah satu lingkup seluk beluk bentuk kata yang penting dipelajari. Hal itu berkaitan dengan makna baru yang ditimbulkan dari proses komposisi itu terkadang sangat berbeda dari bentuk dasarnya. Dari beberapa kosakata yang ada dalam penelitian ini memberikan kesempatan kepada peserta didik untuk berpikir lebih kritis. Penelitian ini juga dapat memberi tambahan pemahaman ilmu pengetahuan dalam hal memahami konsep teori linguistik, khususnya bidang morfologi yang berkaitan dengan komposisi atau pemajemukan.

\section{Daftar Pustaka}

Chaer, A. (2008). Morfologi Bahas Indonesia. Jakarta: PT. Rineka Cipta.

Ermanto, E. (2016). Proses Morfologi Infleksi pada Adjektiva Bahasa Indonesia. Humanus, 12(2), 41. doi:10.24036/jh.v15i1.6411 
Fauziyah, S. W. (2020). Kata Majemuk dalam Teks Berita Daring CNN Internartional Edisi September 2019: Kajian Morfologi. Suar Betang, 15(1), 35-44. doi:10.26499/surbet.v15i1.143

Kridalaksana, H. (2007). Pembentukan Kata dalam Bahasa Indonesia. Jakarta: PT Gramedia Pustaka Utama.

Kridalaksana, H. (2008). Kamus Besar Bahasa Indonesia. Ed. IV. Jakarta: PT Gramedia Pustka Utama.

Kridalaksana, H. (2008). Kamus Linguistik. Ed. IV. Jakarta: PT Gramedia Pustka Utama.

Masinambow, E.K.M. \& Haenen, P. (2002). Bahasa Indonesia dan Bahasa Daerah. Jakarta: Yayasan Obor Indonesia.

Muslich, M. (2010). Tata Bentuk Bahasa Indonesia. Jakarta: Bumi Aksara.

Noermanzah, N. (2017). Struktur Kalimat Tunggal Bahasa Sindang di Kota Lubuklinggau dan Pengaruhnya dalam Pembelajaran Bahasa Indonesia. AKSIS: Jurnal Pendidikan Bahasa dan Sastra Indonesia, 1(1), 2. doi:10.21009/aksis.010101

Putri, M. H. (2014). Komposisi dan Makna Idiomatikal Kata Majemuk Nomina dalam Koran Kougaku Edisi 1 Juni 2011. Jurnal IImiah Mahasiswa FIB, 7(7),http://jimbastrafib.studentjournal.ub.ac.id/index.php/jimbastrafib/article /view/762

Ramlan, M. (2009). Morfologi Suatu Tinjauan Deskriptif. Yogyakarta: CV Karyono.

Soeparno. (2002). Dasar-Dasar Linguistik Umum. Yogyakarta: Tiara Wacana.

Sudaryanto. (1993). Metode dan Aneka Teknik Analisis Bahasa. Yogyakarta: Duta University Press.

Suhardi. (2008). Sintaksis. Yogyakarta: UNY Press.

Verhaar, J.W.M (1996) Asas-asas Linguistik Umum. Yogyakrta: Gajah Mada University.

Wahidah, B. Y. K. (2019). Komparasi Berbagai Definisi Mengenai Frasa dan Kata Majemuk dalam Media Sosial Google Berdasarkan Kajian Sintaksis. JUPE : Jurnal Pendidikan Mandala, 4(5). doi:10.36312/jupe.v4i5.853

Yasiroh, N. (2013). "Proses Morfologis Bahasa Melayu Palembang". Thesis. Universitas Negeri Yogyakarta. 